\title{
Land management modulates the environmental controls on global earthworm communities
}

Article

Accepted Version

Johnston, A. S. A. (2019) Land management modulates the environmental controls on global earthworm communities. Global Ecology and Biogeography, 28 (12). pp. 1787-1795. ISSN 1466-8238 doi: https://doi.org/10.1111/geb.12992 Available at https://centaur.reading.ac.uk/85572/

It is advisable to refer to the publisher's version if you intend to cite from the work. See Guidance on citing.

To link to this article DOI: http://dx.doi.org/10.1111/geb.12992

Publisher: Wiley

All outputs in CentAUR are protected by Intellectual Property Rights law, including copyright law. Copyright and IPR is retained by the creators or other copyright holders. Terms and conditions for use of this material are defined in the End User Agreement.

www.reading.ac.uk/centaur

\section{CentAUR}


Central Archive at the University of Reading

Reading's research outputs online 


\section{Land management modulates the environmental controls on global earthworm} communities

Alice S.A. Johnston ${ }^{1 *}$

${ }^{1}$ School of Biological Sciences, University of Reading, UK.

* Corresponding Author:

alice.johnston@reading.ac.uk; +44 (0)118 3786439

School of Biological Sciences, University of Reading, Reading, RG6 6AH

Running title: Global patterns in earthworm communities

\section{Abstract}

Aim: Soils and their biological communities face increasing pressure from multiple global drivers, including land management and climate change. In soils, earthworms play key roles in ecosystem functioning, but the environmental controls on their global communities are not fully understood. Here, an earthworm dataset was compiled to investigate the effects of environmental variables and land management on global earthworm communities. Location: $40^{\circ} \mathrm{S}-65^{\circ} \mathrm{N}$.

Time period: 1962 to 2016 .

Major taxa studied: Earthworms

Methods: A dataset of 899 earthworm community observations, together with environmental variables, was compiled across 169 globally distributed sites. Sites included natural forest and grassland or managed arable, pasture and plantation ecosystems. Total, anecic, endogeic and epigeic abundances and total species richness were compared in natural and managed ecosystems to quantify the effects of land management across climates. A hierarchical model was used to test the importance of environmental controls in predicting the relationship between total earthworm species richness and abundance at a global scale. 
Results: Land management prompted little change in total earthworm abundance at the global scale, but reduced species richness and shifted community composition. Endogeic earthworms were more abundant in managed ecosystems, while anecic and epigeic earthworms show variable responses across ecosystem types. Global relationships between total earthworm species richness and abundance were explained by climate, soil pH and land management.

Main conclusions: Land management modulates the effects of environmental controls on global earthworm communities, through direct disturbance and indirect changes in edaphic conditions.

Keywords: earthworms; community composition; species richness; land management; soil $\mathrm{pH}$; climate.

\section{Introduction}

Global environmental drivers are placing increasing pressures on soils, with shifts in soil biodiversity and community composition reducing ecosystem resilience (Wagg et al., 2014; Smith et al., 2016). In soils, earthworms act as important ecosystem engineers. By burrowing through the soil, earthworms influence soil aggregation and structure (Lavelle et al., 2006) while their feeding and casting activities stimulate the decomposition of plant material and encourage other beneficial soil organisms (Blouin et al., 2013). As 'nature's plough', the activities of earthworms are particularly beneficial in managed ecosystems (Darwin, 1881), and conservation management practices often aim to optimise soil environmental conditions (e.g. soil organic carbon (SOM) and soil moisture) for earthworm proliferation (Rounsevell et al., 2010). In turn the effects of earthworm activity on soil aggregate stability, water regulation and carbon and nutrient cycling improve crop yields and soil carbon storage (Shuster et al., 2001; van Groenigen et al., 2014). Exotic earthworm species, on the other hand, have invaded most areas of the globe (Hendrix et al., 2008), and 
when introduced into previously unoccupied areas can act as strong drivers of ecosystem change (Hendrix, 2006; Eisenhauer, 2010; Craven et al., 2017).

Despite the long known impact of earthworms on soil fertility (Darwin, 1881), relatively few attempts have been made to investigate large-scale patterns in earthworm communities (Decaëns, 2010). Generally, earthworm communities are thought to become more complex and diverse towards the equator (Lavelle, 1983). Climatic factors (temperature and precipitation) are considered fundamental drivers of these latitudinal trends in earthworm communities (Brussaard et al., 2012; Rutgers et al., 2016), but such inferences are based on limited data (Fierer et al., 2009; Decaëns, 2010; Brussaard et al., 2012). Other environmental variables have also been reported to structure earthworm communities. For instance, earthworm abundance increases with soil organic carbon (SOC) content across ecosystem types and management intensity (Hendrix et al., 1992), while species richness tends to decline with increasing SOC availability (Bouché, 1972). Earthworm community responses to disturbance through soil management show much more general trends at regional and global scales (Decaëns \& Jiménez, 2002; Decaëns et al., 2003; Spurgeon et al., 2013). In a global meta-analysis, Briones and Schmidt (2017) found that earthworm population abundance and biomass declined with increasing tillage intensity, but also depended on variations in soil, environmental, climatic and management conditions as well as the different sensitivities of earthworm ecological groups.

Earthworms are typically classified into three broad ecological groups (epigeic, anecic and endogeic), which play different roles in ecosystem functioning and display different responses to management and environmental changes (Blouin et al., 2013). Epigeic (surface-living) and anecic (vertical burrowing) earthworms rely on leaf litter for habitat and food, and when this is disturbed by management practices such as tillage, their numbers are largely reduced (Briones \& Schmidt, 2017; Johnston et al., 2018). Thus, managed soils are often dominated by endogeic species, which live in temporary horizontal burrows in the 
mineral soil (Riley et al., 2008). Although endogeic earthworms do offer beneficial soil functions in managed soils, more diverse earthworm populations are needed in order to optimise ecosystem functioning under sustainable land management (Eisenhauer \& Schädler, 2011; Blouin et al., 2013). For instance, anecic earthworms are particularly beneficial for enhancing plant production (van Groenigen et al., 2014), through greater mineralisation of carbon and nutrients from plant material (Postma-Blaauw et al., 2006). Mineralisation of SOC, on the other hand, is enhanced by endogeic and not anecic earthworms (Postma-Blaauw et al., 2006), while the feeding and burrowing activities of epigeic and anecic earthworms increase water infiltration rates but endogeics do not (Spurgeon et al., 2013).

Anticipating the effects of global environmental changes on earthworm communities and their activities requires a more comprehensive understanding of the environmental controls on their global distribution, in both natural and managed ecosystems. Previous studies on large-scale biogeographical distributions of soil microbes (bacteria and fungi) have revealed strong relationships between soil pH and soil organic matter (Fierer \& Jackson, 2006; Tedersoo et al., 2014; Malik et al., 2018) whereas those on soil animals suggest a closer relationship with climatic conditions (Wall et al., 2008; Bates et al., 2013; Gibb et al., 2015). Here, the working hypothesis was that biogeographic patterns in earthworm communities are fundamentally similar to other soil animals, with climatic variables structuring earthworm communities in both natural and managed ecosystems. In managed ecosystems, declines in species richness and shifts in community composition to endogeic earthworm dominance was also expected (Kladivko, 2001). To test these hypotheses, a global earthworm dataset was compiled across boreal, temperate, mediterranean and tropical climates, covering both natural (forests and grasslands) and managed (arable, pasture and plantation) ecosystems. 


\section{Methods and Material}

\subsection{Data collection}

112 Studies of earthworm field populations and communities were synthesised, using ISI Web of

113 Knowledge (www.webofknowledge.com). To be included in the dataset, studies had to report

114 field-collected population abundances and/or species richness in un-manipulated field

115 conditions. That is, mesocosm experiments and experimental field trials that manipulated

116 environmental variables were excluded. Search terms included macrofauna, earthworm or

117 oligochaete and excluded the terms laboratory, microcosm or mesocosm in the title.

118 Additional search terms for the topic included: population or community; abundance, density,

119 number or species richness; and field, forest, grassland, arable, plantation, pasture,

120 agricultural, managed or natural. Field studies were also excluded if they did not report

121 essential site information such as latitude, longitude or site location, or the year/month of

122 earthworm collection to extract climatic data. Following the initial literature search, data gaps

123 for under-represented climates or ecosystems (e.g. natural ecosystems in mediterranean or

124 managed ecosystems in boreal climates) were addressed using specific search terms in

125 Web of Knowledge to ensure comparable sample sizes between climates. A total of 135

126 studies met the search criteria, which covered 169 globally distributed study sites (Figure 1)

127 over a period spanning 1962 to 2016. 

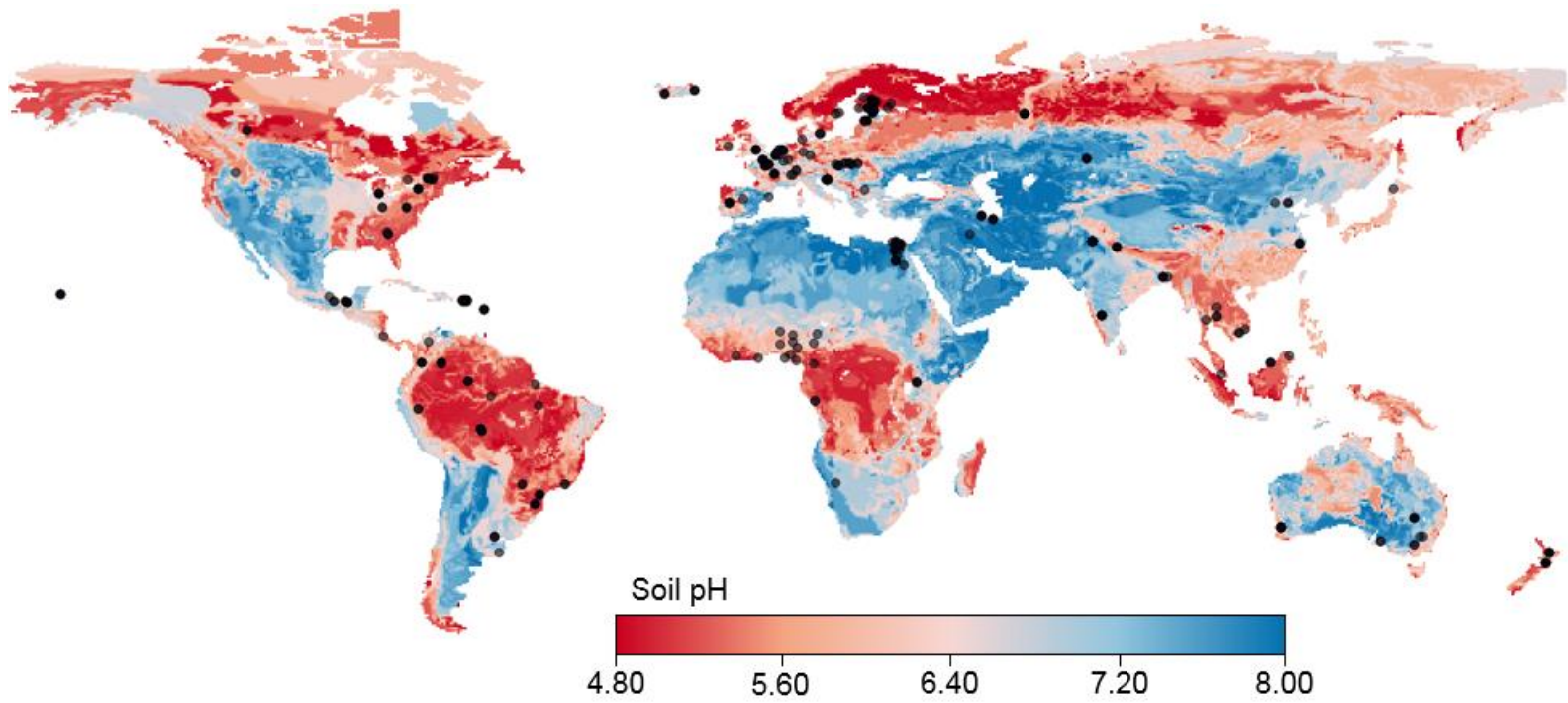

Figure 1. Geographic distribution of study sites $(n=169)$ across 135 studies compiled in the earthworm dataset, displayed over a world soil pH map (IGBP-DIS, 1998).

\subsection{Data summary}

Most studies combined hand sorting and formaldehyde extraction methods for earthworm sampling, and abundance was typically measured as individuals $\mathrm{m}^{-2}$. Cocoons were rarely reported and so not included in average abundance measures, whereas adults and juveniles were summed to give total species abundance where relevant. The raw earthworm dataset $(\mathrm{N}=1583)$, reported seasonal earthworm population abundances and species richness where available, and seasonal or annual population dynamics by species, ecological group or total earthworm community. Where seasonal earthworm measurements were provided, and when replicates were given for the same sites, population abundances were averaged to give annual and site-specific measurements. If species richness measurements were not provided but species-specific abundances were reported, the number of species recorded was included in the dataset. Ecological group data $(\mathrm{N}=398)$ were summarised by classifying earthworm species by their broad ecological group (anecic, endogeic and epigeic) and summing species-specific earthworm abundances in each group for single sites. Total earthworm community data $(N=501)$, were summed for ecological groups 
recorded at a single site, alongside measurements for total earthworm abundance and species richness.

Environmental variables include mean annual temperature (MAT), mean annual precipitation (MAP), soil moisture, $\mathrm{pH}$, litter layer, soil organic carbon (SOC), total $\mathrm{C}, \mathrm{N}$ and $\mathrm{P}, \mathrm{C}: \mathrm{N}, \mathrm{N}: \mathrm{P}$ and $\mathrm{C}: \mathrm{P}$ ratios. If soil organic matter (SOM, \%) measurements were available, the standard conversion factor of SOC $=\mathrm{SOM} \times 0.58$ was used (Guo \& Gifford, 2002). When soil properties were reported according to soil layer, an average value for all soil layers was calculated. Missing climate data were filled using global climate databases if latitude and longitude and study month/s and/or year were reported. Monthly air temperatures (study temperature, ST) and precipitation (study precipitation, SP) measurements, together with MAT and MAP if not reported, were compiled from local NOAA weather stations (https://www.ncdc.noaa.gov/cdo-web/datatools/findstation).

The data were finally summarised by categorising study sites as boreal, temperate, mediterranean and tropical climates and ecosystem type (natural forests or grasslands, or managed arable, pasture or plantation ecosystems). Extrapolation was necessary in some cases, for instance by including subtropical studies within the tropical climate category and managed grasslands or forests as pastures or plantations, respectively. Managed ecosystems also included a variety of management practices. For instance, arable fields ranged from organic and conservation agriculture to conventional management schemes.

\subsection{Data analysis}

Data analysis was performed in the R environment software (RCoreTeam 2018) and focused on explaining relationships between global earthworm communities and environmental variables. First, differences in total earthworm species richness and abundance and ecological group abundance were analysed across climates, ecosystem types and management groups. Then, a hierarchical model was used to test the importance 
176 of environmental controls in predicting the relationship between total earthworm species

177 richness and abundance at a global scale.

\subsubsection{Land management effects on global earthworm communities}

Differences in total earthworm species richness and abundance and ecological group abundance across climates, ecosystem types and management groups were analysed using all available measurements in the datasets. The effect of land management on total earthworm abundance and species richness was tested using independent-samples t-tests, with $p<0.05$ supporting a difference between the two groups (natural vs managed ecosystems). The effects of climate (tropical, mediterranean, temperate and boreal) and ecosystem type (forest, grassland, arable, pasture or plantation) on total earthworm species richness and abundance, and the effects of both land management and climate on ecological group (anecic, endogeic, epigeic) abundance, were tested using one-way ANOVA's and again taking $p<0.05$ to support a difference between groups.

Earthworm and environmental data were then summarised according to ecosystem type ( $N$ $=18$ ) to investigate general relationships across climates and natural or managed ecosystems. The effects of land management on total, anecic, endogeic and epigeic earthworm abundance were summarised by comparing observed abundances in different across ecosystem types and managed and natural ecosystems were further made at the global scale. 


\subsubsection{Multiple controls on global earthworm communities}

Scaling relationships between earthworm species richness $(S R)$ and abundance $(A)$ were analysed to investigate differences between climates and ecosystem type. First, the $S R-A$ relationship was analysed without, and then with, interactions between $A$ and climate (boreal, temperate, mediterranean, tropical) and $A$ and management (natural or managed). Hierarchical models were then used to test the importance of environmental variables in predicting differences in earthworm species richness and abundance relationships at a global scale. The hierarchy of terms tested followed an order similar to that suggested by de Vries et al. (2012), in which 'controls' are added before 'function'. That is, variables that cause variations in multiple soil properties (e.g. climate) were added first, so that if 'controls' explain the variation in 'functions' then addition of these variables do not improve model likelihood. Terms were added in the order: climate (MAT, MAP, ST, SP and component 1 of PCA's for each combination of the four variables), soil type $(\mathrm{pH}$, soil moisture, $\mathrm{SOC}$ and PCA's), management (natural or managed) and nutrients (C:N, N:P, C:P and PCA's). Each variable was added as a linear or quadratic term, with and without interactions with $A$. Models were then compared by testing their influence on goodness of fit (Akaike's Information Criterion, AIC), model likelihood (Chi-square $p<0.05)$ and parsimony $(\triangle \mathrm{AIC}>2$ for additional degrees of freedom). Models that met these criteria were tested with the subsequent environmental variables. All regression models were performed with averaged $S R$ and $A$ measurements for each ecosystem type $(\mathrm{N}=18)$ and weighted using the reciprocal of the variance of $S R$ to account for differences in sample sizes. The independent effects of key environmental variables, identified by the hierarchical model, were then illustrated by correcting species richness for abundance and the other explanatory environmental variables in the hierarchical model. 


\section{Results}

228

\subsection{Land management effects on global earthworm communities}

230 Total earthworm species richness and abundance differed significantly with climate (ANOVA

231 for species richness: $F=18.62, p<0.0001$; and abundance: $F=16.84, p<0.0001)$ and

232 ecosystem type (species richness: $F=7.90, p<0.0001$; and abundance: $F=24.68, p<$

233 0.0001) (Figure 2). At a global scale, total earthworm species richness and abundance

234 differed in natural and managed ecosystems (independent-samples t-test for species

235 richness: $\mathrm{t}=4.58, p<0.0001$; and abundance: $\mathrm{t}=-2.86, p=0.005)$ (Figure 2). Shifts in

236 species richness and abundance, however, were highly variable across ecosystem types.

237 For instance, earthworm species richness declined in most managed compared to natural 238 ecosystems within climates (Figure 2a), whereas total earthworm abundance displayed a 239 much more variable response (Figure 2b). 

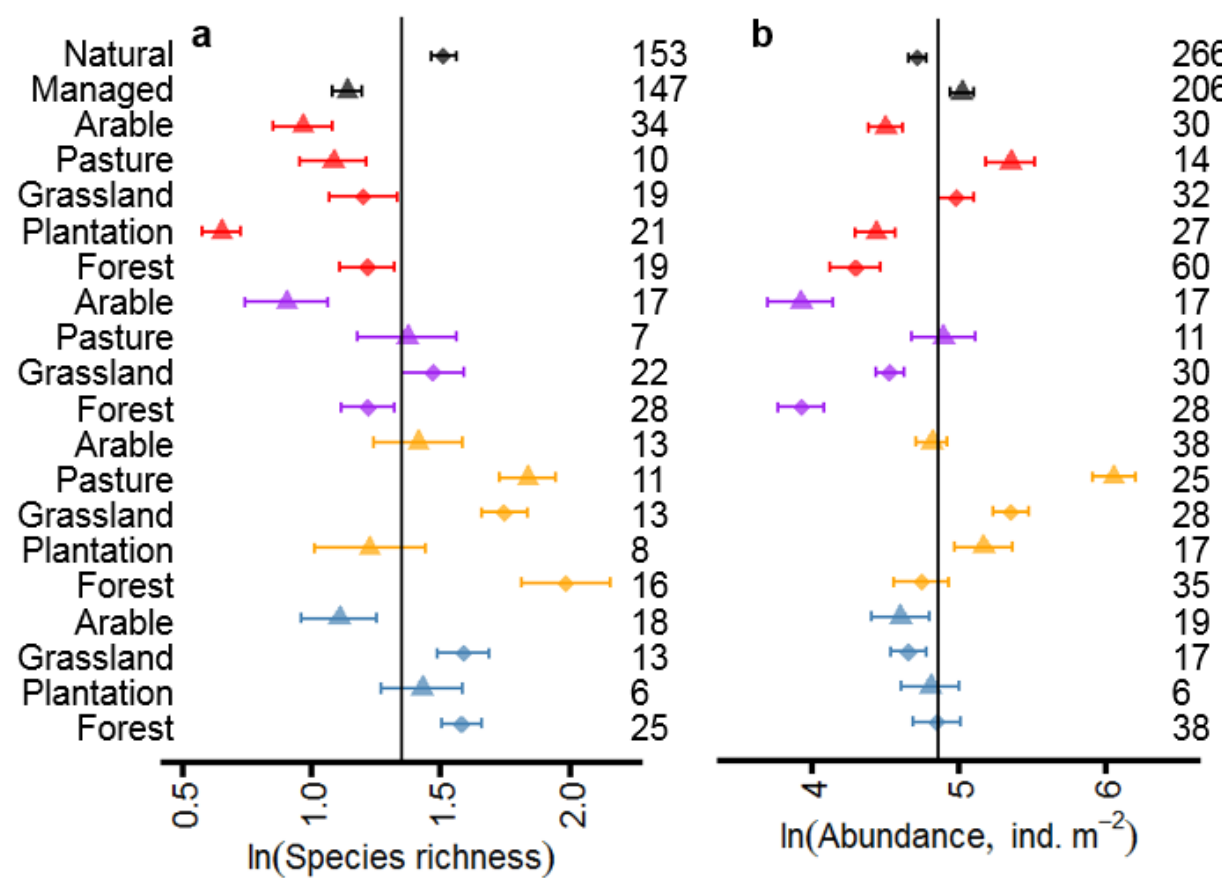

- Global

- Tropical

- Mediterranean

- Temperate

- Boreal

$\diamond$ Natural

$\Delta$ Managed

Figure 2: Earthworm species richness and total abundance across global ecosystems (black: global, red: tropical, purple: mediterranean, orange: temperate, blue: boreal climates and diamonds: natural, triangles: managed ecosystems). Presented values are average a) earthworm species richness and b) total abundance with standard error bars. Solid black vertical lines indicate global averages across climates and ecosystem types. Number of data points are presented on the right-hand side of each plot.

Earthworm community composition was summarised by the relative abundance of the three ecological groups of earthworms: anecic, endogeic and epigeic, which reflect different habitat needs and so sensitivity to soil disturbance. Analysis of the available ecological group data $(\mathrm{N}=398)$ revealed that anecic, endogeic and epigeic abundances interacted significantly with climate $(F=4.96, p<0.0001)$, ecosystem type $(F=18.43, p<0.0001)$ and land management $(F=10.38, p<0.0001)$. At a global scale, total, endogeic and epigeic earthworm abundance increased, while anecic earthworm abundance declined, in response to land management (Figure 3). Similar to total earthworm abundance (Figure 2), however, ecological group abundance was highly variable across different ecosystem types (Table S1). For instance, although there was little difference in total earthworm abundance in natural and managed ecosystems across the different climates, there were greater declines in abundance in arable compared to grassland ecosystems and increases in abundance in 
260 pasture compared to grassland ecosystems (Figure 3). Effects on total earthworm

261 abundance also disguised greater declines in anecic and epigeic earthworms in managed

262 ecosystems due to increases in endogeic earthworm abundance in all managed compared

263 to natural ecosystems, particularly pastures (Figure 3).

264 


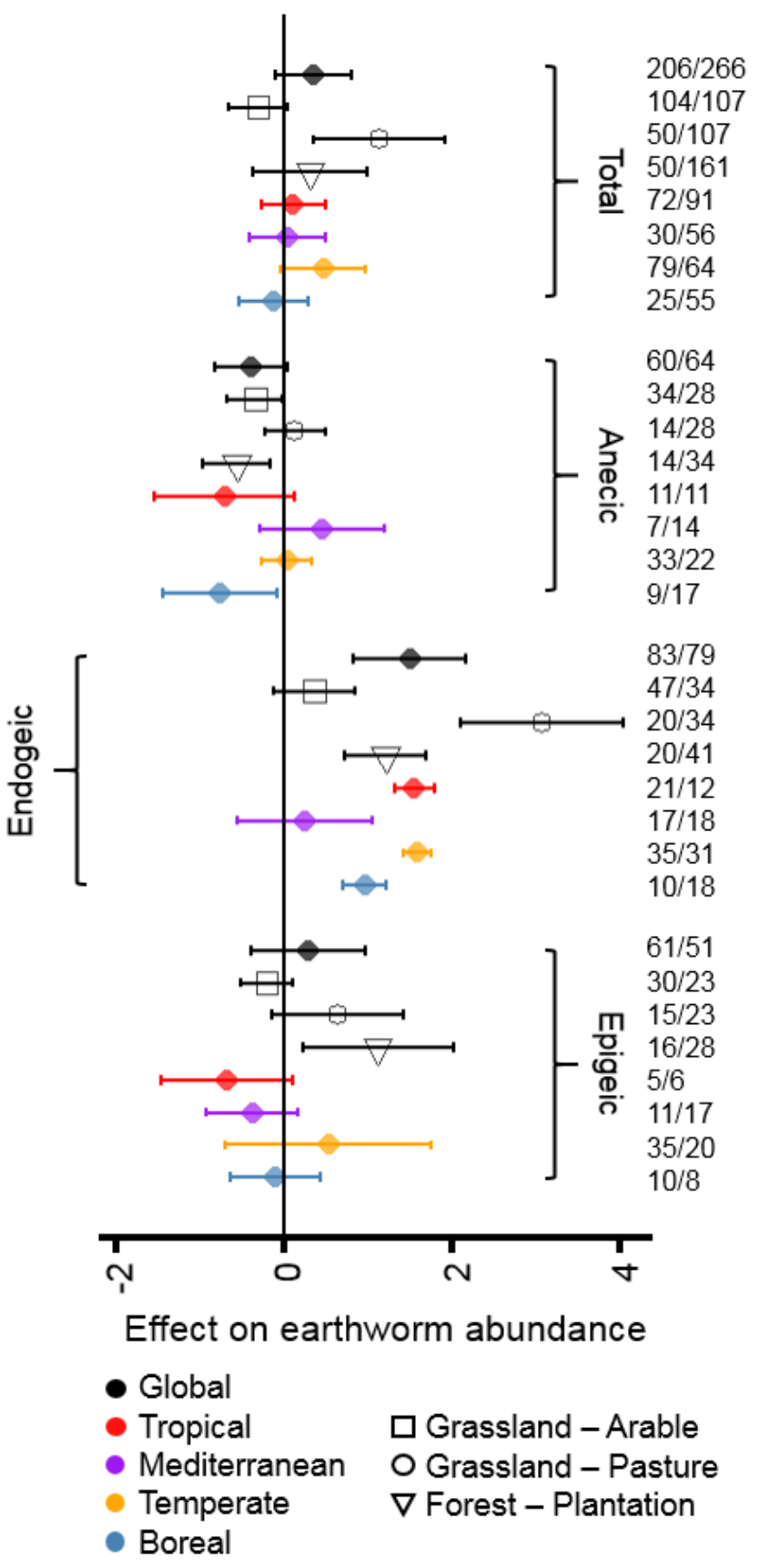

267 Figure 3. Land management effects on total earthworm, anecic, endogeic and epigeic abundance. Effect sizes are calculated by comparing abundances in natural and managed ecosystems at a global scale (black symbols) or across climates (red: tropical, purple: mediterranean, orange: temperate, blue: boreal climates) and between specific natural and managed ecosystem types (square symbols: grassland and arable, circle symbols: grassland and pasture, triangle symbols: forest and plantation). Presented values are average effect sizes with standard error bars. Number of data points are presented on the right-hand side for the natural and managed ecosystems. 


\subsection{Multiple controls on global earthworm communities}

275 Divergent earthworm responses to land management resulted in different scaling relationships between earthworm species richness and total abundance at a global scale (Figure 4). That is, the relationship between earthworm species richness and abundance was better explained by differences between natural and managed ecosystems than null or climate models (Table S2). There was no significant interaction between abundance and management, however, as abundance was generally unaffected by land management at a global scale (Figure 3).

282

283

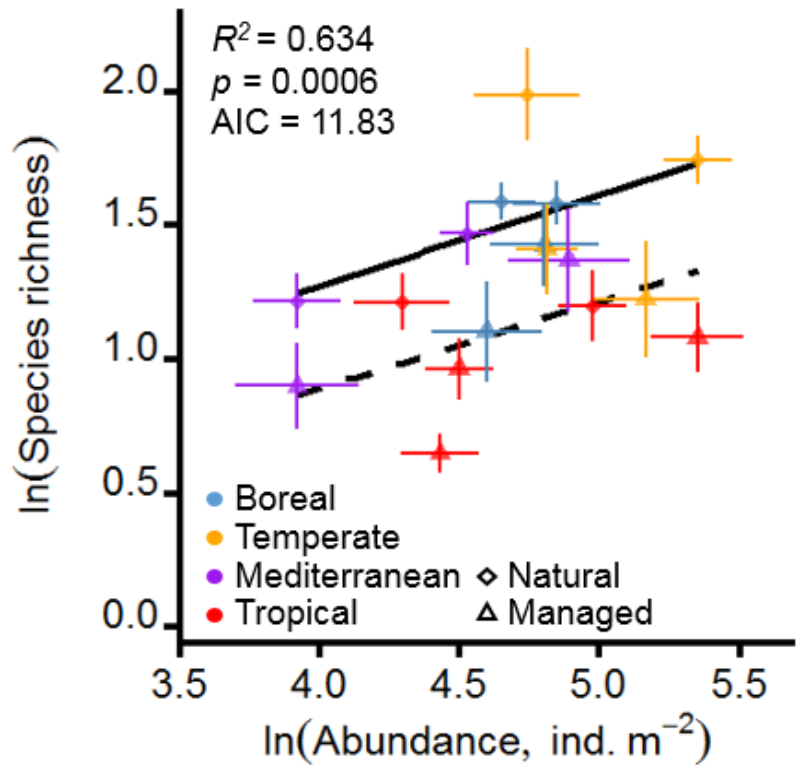

Figure 4. Scaling relationships between earthworm species richness and total abundance across climates (red: tropical, purple: mediterranean, orange: temperate, blue: boreal) and ecosystem types (diamonds: natural, triangles: managed) $(\mathrm{N}=18)$. Linear regressions between abundance and species richness differed in natural (diamond symbols and solid line) and managed (triangle symbols and broken line) ecosystems (Table S2).

A hierarchical model was used to test the importance of environmental controls on global relationships between earthworm species richness and abundance (Figure 4 and Table S1). Addition of three terms improved the hierarchical model fits in comparison to the null model (Table $1, \mathrm{AIC}=23.77$ ), with the condition that adding an additional term must be met with a goodness of fit of $\triangle \mathrm{AIC}>2$ and Chi-square $p<0.05$. Climate $\mathrm{PCA}$, measured as component 
2941 of a PCA conducted with MAT, MAP, ST and SP explained the effects of climate better

295 than MAT, MAP, ST or SP separately, or any other PCA between the variables. Overall, the

296 quadratic climate term explained $56 \%$ of the variation in species richness-abundance

297 relationships compared to the null model. An interaction term with soil pH and management

298 explained an additional 8 and $10 \%$ of the variation in global earthworm patterns

299 respectively. The final model had a greatly improved goodness of fit to the data and model

300 likelihood compared to the null model $(\triangle \mathrm{AIC}=46.46$, Chi-square $p<0.0001)$. The

301 hierarchical model also showed an improved goodness of fit and model likelihood in

302 comparison to the management model (Figure 4, $\Delta \mathrm{AIC}=34.52$, Chi-square $p<0.0001$ ).

303 Importantly, the hierarchical model further revealed the environmental variables

304 underpinning shifts in the relationship between global earthworm species richness and

305 abundance with climate and land management.

306 


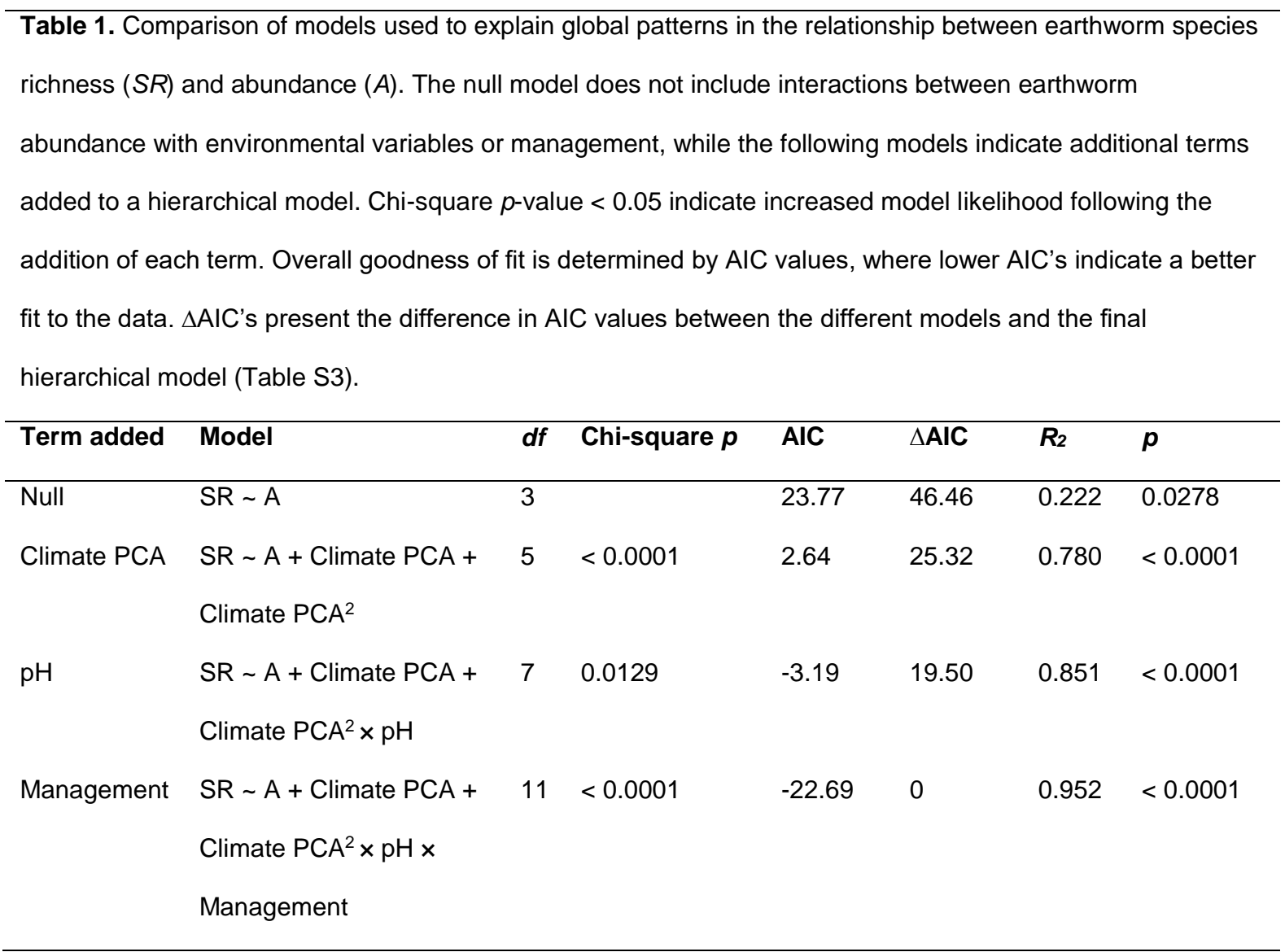

The independent effects of climate (component 1 of a PCA conducted with MAT, MAP. ST and SP) and soil pH were illustrated by correcting species richness for abundance and the other explanatory environmental variables in the hierarchical model (Figure 5). For example, climate effects were assessed by correcting species richness for abundance, soil $\mathrm{pH}$, and management effects according to regression coefficients. Then, linear and quadratic models between corrected species richness and the independent variable were tested with and without interaction terms between the environmental variable and management. Results revealed linear declines in corrected abundance with increasing Climate PCA (increasing MAT, MAP, ST and SP) (Figure 5a) and a polynomial relationship between corrected species richness with soil pH (Figure 5b), and significant interactions between natural and managed ecosystems. 

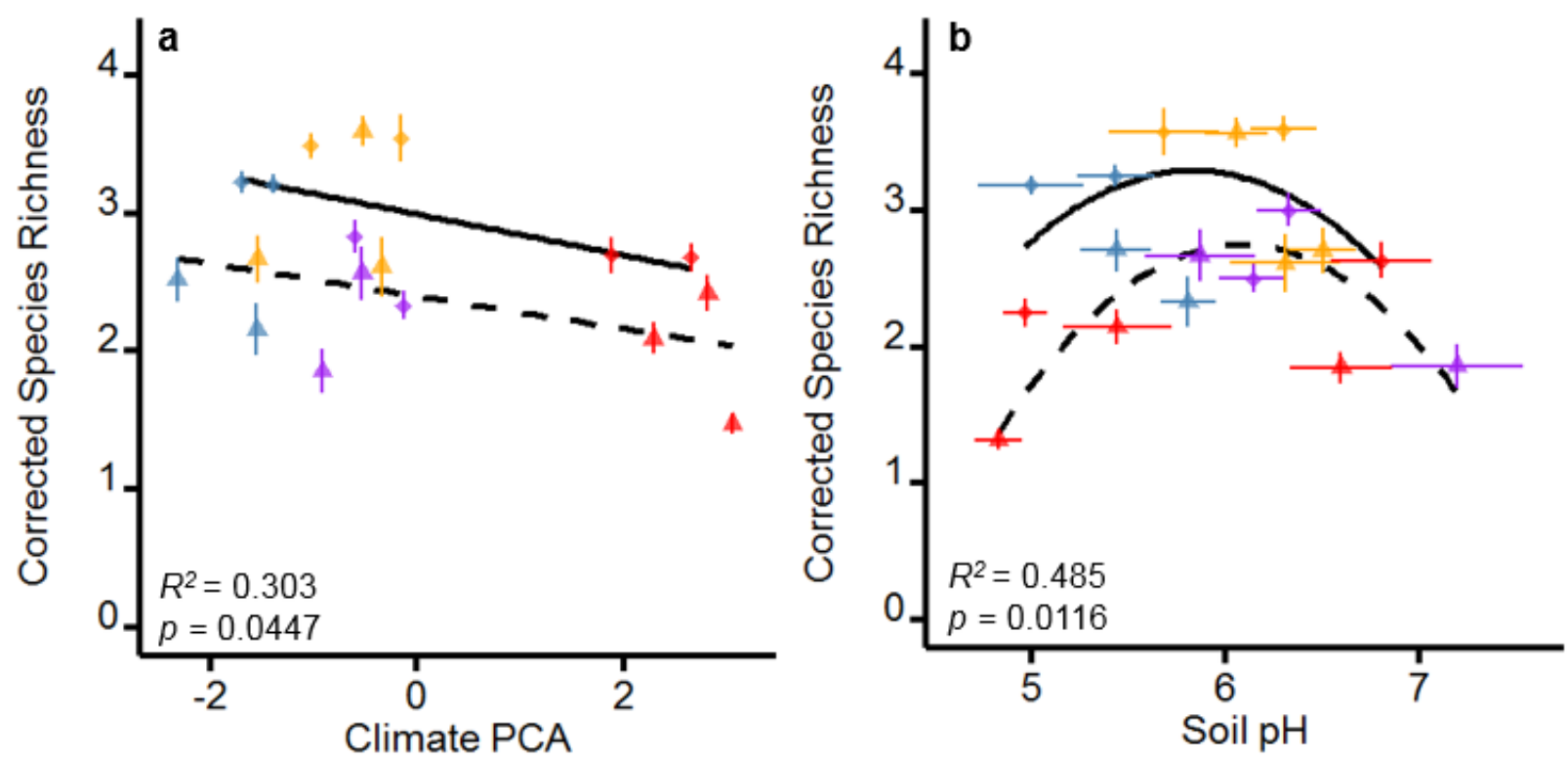

Figure 5. Relationships between corrected earthworm species richness with a) climate PCA and b) soil pH across natural (solid lines) or managed (broken lines) ecosystems and climates (symbol colours and shapes as in Figure 4). Species richness data were corrected for non-fixed explanatory variables as described in the text.

\section{Discussion}

Compilation of a global dataset in this study (Figure 1) reveals surprising similarities and expected differences in earthworm communities between natural and managed ecosystems. Across four climates total earthworm abundance showed little response to land management, while species richness was consistently reduced in managed compared to natural ecosystems (Figure 2). These patterns can be largely explained by shifts in earthworm community composition in managed ecosystems, which are generally composed of fewer anecic and epigeic and more endogeic earthworms than natural ecosystems (Figure 3). Scaling relationships between earthworm species richness and total abundance differed in natural and managed ecosystems (Figure 4). A hierarchical model was used to show that climate, soil $\mathrm{pH}$ and land management best explained global variations in earthworm communities (Table 1 and Figure 5).

Earthworm species richness and total abundance were highest in temperate and lowest in mediterranean climates, while abundance was comparable in tropical and boreal but species 
richness higher in boreal than tropical climates (Figure 2). Climate thus strongly influences

342 global earthworm communities, as hypothesised, through individual physiological and behavioural responses to temperature and soil water extremes (Johnston et al., 2018). Interestingly, this study indicates non-linear latitudinal shifts in earthworm species richness, previously thought to increase from high to low latitudes (Lavelle, 1983). Nevertheless, these global patterns reflect known relationships between soil biodiversity with temperature and precipitation regimes (Brussaard et al., 2012). Temperate climates, however, have been more extensively studied than any of the other climates investigated here. Differences in sampling timing in colder climates will also introduce some bias as they were typically sampled in the growing season, and earthworm species are known to display varying sensitivities to soil temperature and water fluctuations (Briones et al., 2009). General gaps in earthworm taxonomy (Decaëns, 2010) further limits the current dataset not only to measures of abundance and species richness, but also to those earthworms that have been identified at the species level.

Overall, earthworm abundance increased in managed compared to natural ecosystems globally and across all but boreal climates (Figure 3). This global pattern could be largely explained by expected shifts in earthworm community composition to greater abundances of endogeic earthworms in managed ecosystems (Riley et al., 2008; Kanianska et al. 2016). Anecic and epigeic earthworm responses to land management, in comparison, were less extreme than expected given the higher vulnerability of these ecological groups to soil disturbance (Briones \& Schmidt, 2017). Although anecic and epigeic abundances declined in arable compared to grassland ecosystems globally, both ecological groups responded positively to pasture compared to grassland ecosystems alongside endogeic earthworms (Figure 3). Livestock grazing is well known to increase earthworm density through the creation of earthworm hotspots of all ecological groups around dung pats (Bacher et al., 2018), but the global extent of this pattern has not been previously reported. Epigeic earthworms also responded positively to temperate plantation compared to forest 
ecosystems (Figure 3 and Table S1), suggesting a competitive advantage of epigeic earthworms in managed forests. Much less data, however, was available for ecological groups compared to total earthworm abundances across the range of ecosystems studied here.

Global relationships between earthworm species richness and abundance in natural and managed ecosystems (Figure 4) were best explained by climate, soil pH and land management (Table 1). Illustrating the independent effects of climate and soil pH in Figure 5 shows how corrected species richness declines with increasing temperature and precipitation (which are positively correlated with climate PCA, Figure 5a) and changes according to a polynomial relationship with soil pH (Figure 5b). Climate PCA captures increasing mean annual and study temperatures and mean annual and study precipitations (except for a decline in mediterranean climates) from boreal to tropical climates. Earthworm species richness thus declines with greater monthly temperatures $\left(>12^{\circ} \mathrm{C}\right)$ and with both lower $(<40 \mathrm{~mm})$ and greater monthly precipitation $(>130 \mathrm{~mm})$. Although species richness measurements will be influenced by greater sampling effort in moderate climatic conditions, similar patterns in natural and managed ecosystems suggest consistent climate effects on earthworms (Figure 5a). On the other hand, the decline in earthworm species richness between natural and managed ecosystems was greater in more acidic soils $(\mathrm{pH}<6)$ compared to near-neutral soils $(\mathrm{pH}>6)$ (Figure 5b).

Reduced species richness in managed ecosystems is typically associated with an increase in soil $\mathrm{pH}$ at the ecosystem scale. For instance, species richness of earthworm communities was reduced across all climates in arable fields compared to grasslands while soil pH was usually higher in arable compared to grassland ecosystems. In contrast, greater species richness in temperate pastures compared to grasslands was associated with a decline in soil $\mathrm{pH}$ (Table S1). Different soil pH changes in managed ecosystems tend to reflect varying management intensities (Malik et al., 2018). Reductions in soil pH in tropical arable 
compared to grassland ecosystems could therefore indicate the widespread adoption of conservation agriculture (based on minimum soil disturbance) in these regions due to the greater potential of tropical soil erosion under intensive management (Labrière et al., 2015). More intensive management practices, such as tillage, have direct effects on earthworm communities through direct mortality, the removal of plant litter and destruction of habitat (Briones \& Schmidt, 2017). Relationships between earthworm communities and soil pH in this study are thus expected to reflect varying extents of plant litter removal and subsequent changes in SOC accumulation in managed ecosystems.

Plant functional traits likely underpin the relationship between climate, soil pH and earthworm communities in both natural and managed ecosystems (Figure 5). In temperate forests, for example, Reich et al. (2005) found variation in leaf litter calcium concentrations to be a key driver of long-terms changes in soil pH, earthworm abundance and biomass, and litter decomposition rates. Although relationships between soil C:N:P stoichiometry and earthworm communities were not identified in this study, soil pH reflects the availability of multiple nutrients (e.g. Mulder and Elser (2009)). Different relationships between earthworm ecological groups and soil pH may further indicate successional feedback relationships between plant traits and earthworm communities. Earthworm invasions into previously unoccupied forests, for example, are typically initiated by epigeic species which show a greater tolerance for acidic soils (Hendrix, 2006). Earthworms then feedback to the plant community by accelerating plant litter decomposition and nutrient mineralisation rates and altering microbial community composition (Craven et al., 2017). Earthworm invasions are therefore typically associated with successions in both plant quality and earthworm community composition (Bohlen et al., 2004). Future shifts in temperature and precipitation regimes, alongside changes in land management, will thus alter feedbacks between plant traits, earthworms and multiple soil functions (Wardle et al., 2004). 
424 Disentangling the effects of climatic, edaphic, management and biotic factors on global earthworm distributions requires a better understanding of the mechanisms linking individual species to their populations in site-specific conditions and species populations to earthworm communities at the ecosystem and global scale. Building global soil community databases at the species- and site-specific level could help unravel the mechanisms linking earthworm communities to their environments. First, however, focused empirical studies are needed to address current knowledge gaps in earthworm macroecology. Seasonal fluctuations in earthworm communities in boreal ecosystems and earthworm communities in mediterranean and tropical ecosystems, for example, need to be accounted for. Overall, the results of this study show that global earthworm communities are strongly linked to climate and soil $\mathrm{pH}$, and that land management modulates global relationships between earthworm species richness and environmental controls. Better understanding of macroecological patterns in earthworm communities are needed to aid prediction of the large-scale impacts of land management and climate changes on soil ecosystems.

Acknowledgements. This research has been financially supported by a NERC Soil Security Programme fellowship (NE/N019504/1). Thanks go to T. Sizmur for feedback on the manuscript, E.L. Gardner for discussions on the analysis and the editor and two anonymous reviewers for helpful suggestions which greatly improved the manuscript.

Data availability statement. The dataset compiled and analysed in this study is available from Dryad (https://doi.org/10.5061/dryad.4fn50k3).

References

Bacher, M. G., Fenton, O., Bondi, G., Creamer, R. E., Karmarkar, M., \& Schmidt, O. (2018). The impact of cattle dung pats on earthworm distribution in grazed pastures. $B M C$ Ecology, 18, 59. 
451 Bates, S.T., Clemente, J.C., Flores, G.E., Walters, W.A., Parfrey, L.W., Knight, R. \& Fierer,

452

453

454

455

456

457

458

459

460

461

462

463

464

465

466

467

468

469

470

471

472

473

474

475

476

477

N. (2013) Global biogeography of highly diverse protistan communities in soil. The ISME Journal, 7, 652.

Blouin, M., Hodson, M.E., Delgado, E.A., Baker, G., Brussaard, L., Butt, K.R., Dai, J., Dendooven, L., Peres, G. \& Tondoh, J.E. (2013) A review of earthworm impact on soil function and ecosystem services. European Journal of Soil Science, 64, 161-182.

Bohlen, P.J., Groffman, P.M., Fahey, T.J., Fisk, M.C., Suarez, E., Pelletier, D.M. \& Fahey, R.T. (2004) Ecosystem Consequences of Exotic Earthworm Invasion of North Temperate Forests. Ecosystems, 7, 1-12.

Bouché, M.B. (1972) Lombriciens de France: écologie et systématique. Soil Science, 119, 252.

Briones, M.J.I. \& Schmidt, O. (2017) Conventional tillage decreases the abundance and biomass of earthworms and alters their community structure in a global metaanalysis. Global Change Biology, 23, 4396-4419.

Briones, M.J.I., Ostle, N.J., McNamara, N.P. \& Poskitt, J. (2009) Functional shifts of grassland soil communities in response to soil warming. Soil Biology and Biochemistry, 41, 315-322.

Brussaard, L., Aanen, D., Briones, M., Decaëns, T., De Deyn, G., Fayle, T., James, S. \& Nobre, T. (2012) Biogeography and phylogenetic community structure of soil invertebrate ecosystem engineers, global to local patterns, implications for ecosystem, functioning and services and global, environmental change impacts. Soil Ecology Ecosystems Services, pp. 201-232. Oxford University Press.

Chan, K. (2001) An overview of some tillage impacts on earthworm population abundance and diversity-implications for functioning in soils. Soil and Tillage Research, 57, 179-191.

Craven, D., Thakur, M.P., Cameron, E.K., Frelich, L.E., Beauséjour, R., Blair, R.B., Blossey, B., Burtis, J., Choi, A. \& Dávalos, A. (2017) The unseen invaders: introduced 
earthworms as drivers of change in plant communities in North American forests (a meta-analysis). Global Change Biology, 23, 1065-1074.

Daniel, O. (1991) Leaf-litter consumption and assimilation by juveniles of Lumbricus terrestris L.(Oligochaeta, Lumbricidae) under different environmental conditions. Biology and Fertility of Soils, 12, 202-208.

Darwin, C. (1881) The formation of vegetable mould through the action of worms: with observations on their habits. John Murray, London.

Decaëns, T. (2010) Macroecological patterns in soil communities. Global Ecology and Biogeography, 19, 287-302.

Decaëns, T. \& Jiménez, J.J. (2002) Earthworm communities under an agricultural intensification gradient in Colombia. Plant and Soil, 240, 133-143.

Decaëns, T., Bureau, F. \& Margerie, P. (2003) Earthworm communities in a wet agricultural landscape of the Seine Valley (Upper Normandy, France): The 7th international symposium on earthworm ecology $\cdot$ Cardiff $\cdot$ Wales $\cdot$ 2002. Pedobiologia, 47, 479489.

Decaëns, T., Margerie, P., Aubert, M., Hedde, M. \& Bureau, F. (2008) Assembly rules within earthworm communities in North-Western France_A regional analysis. Applied Soil Ecology, 39, 321-335.

Decaëns, T., Jiménez, J., Barros, E., Chauvel, A., Blanchart, E., Fragoso, C. \& Lavelle, P. (2004) Soil macrofaunal communities in permanent pastures derived from tropical forest or savanna. Agriculture, Ecosystems \& Environment, 103, 301-312.

de Vries, F.T., Manning, P., Tallowin, J.R., Mortimer, S.R., Pilgrim, E.S., Harrison, K.A., Hobbs, P.J., Quirk, H., Shipley, B. \& Cornelissen, J.H. (2012) Abiotic drivers and plant traits explain landscape-scale patterns in soil microbial communities. Ecology Letters, 15, 1230-1239.

Eisenhauer, N. (2010) The action of an animal ecosystem engineer: identification of the main mechanisms of earthworm impacts on soil microarthropods. Pedobiologia, 53, 343352. 
Eisenhauer, N. \& Schädler, M. (2011) Inconsistent impacts of decomposer diversity on the stability of aboveground and belowground ecosystem functions. Oecologia, 165, 403415.

Eisenhauer, N., Stefanski, A., Fisichelli, N.A., Rice, K., Rich, R. \& Reich, P.B. (2014) Warming shifts 'worming': effects of experimental warming on invasive earthworms in northern North America. Scientific Reports, 4, 6890.

Fierer, N. \& Jackson, R.B. (2006) The diversity and biogeography of soil bacterial communities. Proceedings of the National Academy of Sciences of the United States of America, 103, 626-631.

Fierer, N., Strickland, M.S., Liptzin, D., Bradford, M.A. \& Cleveland, C.C. (2009) Global patterns in belowground communities. Ecology Letters, 12, 1238-1249.

Gibb, H., Sanders, N.J., Dunn, R.R., Watson, S., Photakis, M., Abril, S., Andersen, A.N., Angulo, E., Armbrecht, I., Arnan, X., Baccaro, F.B., Bishop, T.R., Boulay, R., Castracani, C., Del Toro, I., Delsinne, T., Diaz, M., Donoso, D.A., Enríquez, M.L., Fayle, T.M., Feener, D.H., Fitzpatrick, M.C., Gómez, C., Grasso, D.A., Groc, S., Heterick, B., Hoffmann, B.D., Lach, L., Lattke, J., Leponce, M., Lessard, J.-P., Longino, J., Lucky, A., Majer, J., Menke, S.B., Mezger, D., Mori, A., Munyai, T.C., Paknia, O., Pearce-Duvet, J., Pfeiffer, M., Philpott, S.M., de Souza, J.L.P., Tista, M., Vasconcelos, H.L., Vonshak, M. \& Parr, C.L. (2015) Climate mediates the effects of disturbance on ant assemblage structure. Proceedings of the Royal Society B: Biological Sciences, 282, 20150418.

Guo, L.B. \& Gifford, R. (2002) Soil carbon stocks and land use change: a meta analysis. Global Change Biology, 8, 345-360.

Hendrix, P.F. (2006) Biological invasions belowground-earthworms as invasive species. Biological Invasions Belowground: Earthworms as Invasive Species, pp. 1-4. Springer. 
Hendrix, P.F., Mueller, B.R., Bruce, R.R., Langdale, G.W. \& Parmelee, R.W. (1992) Abundance and distribution of earthworms in relation to landscape factors on the Georgia Piedmont, U.S.A. Soil Biology and Biochemistry, 24, 1357-1361.

Hendrix, P.F., Callaham Jr, M.A., Drake, J.M., Huang, C.-Y., James, S.W., Snyder, B.A. \& Zhang, W. (2008) Pandora's box contained bait: the global problem of introduced earthworms. Annual Review of Ecology, Evolution, and Systematics, 39, 593-613.

IGBP-DIS (1998) A program for creating global soil-property databases. IGBP Global Soils Data Task, France.

Johnston, A.S., Sibly, R.M. \& Thorbek, P. (2018) Forecasting tillage and soil warming effects on earthworm populations. Journal of Applied Ecology, 55, 1498-1509.

Kanianska, R., Jad’ud’ová, J., Makovníková, J. \& Kizeková, M. (2016) Assessment of relationships between earthworms and soil abiotic and biotic factors as a tool in sustainable agricultural. Sustainability, 8, 906.

Kladivko, E.J. (2001) Tillage systems and soil ecology. Soil and Tillage Research, 61, 61-76.

Labrière, N., Locatelli, B., Laumonier, Y., Freycon, V., \& Bernoux, M. (2015). Soil erosion in the humid tropics: A systematic quantitative review. Agriculture, Ecosystems \& Environment, 203, 127-139.

Lavelle, P. (1983) The structure of earthworm communities. Earthworm ecology, pp. 449466. Springer.

Lavelle, P., Decaens, T., Aubert, M., Barot, S., Blouin, M., Bureau, F., Margerie, P., Mora, P. \& Rossi, J.P. (2006) Soil invertebrates and ecosystem services. European Journal of Soil Biology, 42, S3-S15.

Malik, A.A., Puissant, J., Buckeridge, K.M., Goodall, T., Jehmlich, N., Chowdhury, S., Gweon, H.S., Peyton, J.M., Mason, K.E., van Agtmaal, M., Blaud, A., Clark, I.M., Whitaker, J., Pywell, R.F., Ostle, N., Gleixner, G. \& Griffiths, R.I. (2018) Land use driven change in soil $\mathrm{pH}$ affects microbial carbon cycling processes. Nature Communications, 9, 3591. 
Mulder, C. \& Elser, J.J. (2009) Soil acidity, ecological stoichiometry and allometric scaling in grassland food webs. Global Change Biology, 15, 2730-2738.

Postma-Blaauw, M.B., Bloem, J., Faber, J.H., van Groenigen, J.W., de Goede, R.G.M. \& Brussaard, L. (2006) Earthworm species composition affects the soil bacterial community and net nitrogen mineralization. Pedobiologia, 50, 243-256.

R Core Team (2013) R: A language and environment for statistical computing.

Reich, P.B., Oleksyn, J., Modrzynski, J., Mrozinski, P., Hobbie, S.E., Eissenstat, D.M., Chorover, J., Chadwick, O.A., Hale, C.M. \& Tjoelker, M.G. (2005) Linking litter calcium, earthworms and soil properties: a common garden test with 14 tree species. Ecology Letters, 8, 811-818.

Riley, H., Pommeresche, R., Eltun, R., Hansen, S. \& Korsaeth, A. (2008) Soil structure, organic matter and earthworm activity in a comparison of cropping systems with contrasting tillage, rotations, fertilizer levels and manure use. Agriculture, Ecosystems \& Environment, 124, 275-284.

Rosseel, Y. (2012) Lavaan: An R package for structural equation modeling and more. Version 0.5-12 (BETA). Journal of Statistical Software, 48, 1-36.

Rounsevell, M.D.A., Dawson, T.P. \& Harrison, P.A. (2010) A conceptual framework to assess the effects of environmental change on ecosystem services. Biodiversity and Conservation, 19, 2823-2842.

Rutgers, M., Orgiazzi, A., Gardi, C., Römbke, J., Jänsch, S., Keith, A.M., Neilson, R., Boag, B., Schmidt, O. \& Murchie, A.K. (2016) Mapping earthworm communities in Europe. Applied Soil Ecology, 97, 98-111.

Shuster, W.D., Subler, S. \& McCoy, E.L. (2001) Deep-burrowing earthworm additions changed the distribution of soil organic carbon in a chisel-tilled soil. Soil Biology and Biochemistry, 33, 983-996.

Smith, P., House, J.I., Bustamante, M., Sobocká, J., Harper, R., Pan, G., West, P.C., Clark, J.M., Adhya, T. \& Rumpel, C. (2016) Global change pressures on soils from land use and management. Global Change Biology, 22, 1008-1028. 
Smith, R.G., McSwiney, C.P., Grandy, A.S., Suwanwaree, P., Snider, R.M. \& Robertson, G.P. (2008) Diversity and abundance of earthworms across an agricultural land-use intensity gradient. Soil and Tillage Research, 100, 83-88.

Spurgeon, D.J., Keith, A.M., Schmidt, O., Lammertsma, D.R. \& Faber, J.H. (2013) Land-use and land-management change: relationships with earthworm and fungi communities and soil structural properties. BMC Ecology, 13, 46.

Tedersoo, L., Bahram, M., Põlme, S., Kõljalg, U., Yorou, N.S., Wijesundera, R., Ruiz, L.V., Vasco-Palacios, A.M., Thu, P.Q., Suija, A., Smith, M.E., Sharp, C., Saluveer, E., Saitta, A., Rosas, M., Riit, T., Ratkowsky, D., Pritsch, K., Põldmaa, K., Piepenbring, M., Phosri, C., Peterson, M., Parts, K., Pärtel, K., Otsing, E., Nouhra, E., Njouonkou, A.L., Nilsson, R.H., Morgado, L.N., Mayor, J., May, T.W., Majuakim, L., Lodge, D.J., Lee, S.S., Larsson, K.-H., Kohout, P., Hosaka, K., Hiiesalu, I., Henkel, T.W., Harend, H., Guo, L.-d., Greslebin, A., Grelet, G., Geml, J., Gates, G., Dunstan, W., Dunk, C., Drenkhan, R., Dearnaley, J., De Kesel, A., Dang, T., Chen, X., Buegger, F., Brearley, F.Q., Bonito, G., Anslan, S., Abell, S. \& Abarenkov, K. (2014) Global diversity and geography of soil fungi. Science, 346, 1256688.

van Groenigen, J.W., Lubbers, I.M., Vos, H.M.J., Brown, G.G., De Deyn, G.B. \& van Groenigen, K.J. (2014) Earthworms increase plant production: a meta-analysis. Scientific Reports, 4, 6365.

Wagg, C., Bender, S.F., Widmer, F. \& van der Heijden, M.G. (2014) Soil biodiversity and soil community composition determine ecosystem multifunctionality. Proceedings of the National Academy of Sciences, 111, 5266-5270.

Wall, D.H., Bradford, M.A., St John, M.G., Trofymow, J.A., Behan-Pelletier, V., Bignell, D.E., Dangerfield, J.M., Parton, W.J., Rusek, J., Voigt, W., Wolters, V., Gardel, H.Z., Ayuke, F.O., Bashford, R., Beljakova, O.I., Bohlen, P.J., Brauman, A., Flemming, S., Henschel, J.R., Johnson, D.L., Jones, T.H., Kovarova, M., Kranabetter, J.M., Kutny, L.E.S., Lin, K.-C., Maryati, M., Masse, D., Pokarzhevskii, A., Rahman, H., SabarÁ, M.G., Salamon, J.-A., Swift, M.J., Varela, A., Vasconcelos, H.L., White, D.O.N. \& 

Zou, X. (2008) Global decomposition experiment shows soil animal impacts on decomposition are climate-dependent. Global Change Biology, 14, 2661-2677.

617 Wardle, D.A., Bardgett, R.D., Klironomos, J.N., Setälä, H., van der Putten, W.H. \& Wall, D.H. 618 (2004) Ecological Linkages Between Aboveground and Belowground Biota. Science,

619 304, 1629-1633.

620 